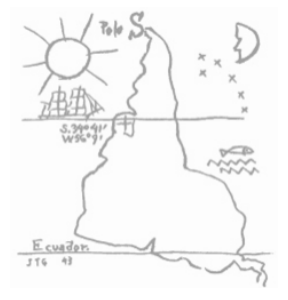

\title{
ALTERNAUTAS
}

Gabriela Loureiro

\section{Necropolitics revisited: how mainstream media coverage of Marielle's shooting in Brazil depoliticises her struggle and reinforces neoliberal logics'}

Alternautas is a peer reviewed academic journal that publishes content related to Latin American Critical Development Thinking.

It intends to serve as a platform for testing, circulating, and debating new ideas and reflections on these topics, expanding beyond the geographical, cultural and linguistic boundaries of Latin America - Abya Yala. We hope to contribute to connecting ideas, and to provide a space for intellectual exchange and discussion for a nascent academic community of scholars, devoted to counter-balancing mainstream understandings of development.

How to cite:

Loureiro, G. (2019), Necropolitics revisited: how mainstream media coverage of Marielle's shooting in Brazil depoliticises her struggle and reinforces neoliberal logics', Alternautas, 6(1), 9-16. URL :

http://www.alternautas.net/blog/necropolitics-revisited

Editor : Alternautas

http://www.alternautas.net

London, UK.

ISSN - 2057-4924 


\section{Necropolitics revisited: how mainstream media coverage of Marielle's shooting in Brazil depoliticises her struggle and reinforces neoliberal logics'}

Until her assassination on the 14th of March 2018, activist Marielle Franco was a voice of her comunidade, the favela of Maré in Rio de Janeiro, and repeatedly denounced police brutality and the genocide of Black people, a topic that is not often covered by mainstream media in Brazil. When Marielle was murdered, pressure by national and international press prompted the ex-president Michel Temer to affirm that the case would be investigated and solved in 48 hours. Many months later, the crime has not yet been solved, although Rio police have identified a group of suspects who are part of a very dangerous militia in the state of Rio de Janeiro, with at least one tie to Jair Bolsonaro's family. The following turbulent months of 2018 made journalists follow other news: the imprisonment of former president Luiz Inácio Lula da Silva, the continuation of Lava Jato's corruption investigation, and the violence and polarization associated with Brazil's presidential elections. The stories about Marielle quickly faded away. When the crime happened, however, there was a considerate amount of coverage by mainstream media. That is the subject of this article.

1 GABRIELA LOUREIRO is a PhD student at the University of West London.

2 This article was originally published http://www.alternautas.net/blog/necropolitics-revisited on February 9th, 2019. 
I will focus on six main problems I identified in Brazilian mainstream press outlets' coverage of the case and a seventh problem related to the media, although not perpetrated by journalists. Firstly, I will examine how there was a delay before appropriate attention was paid to Marielle's shooting. Then, I will speak about how her criticism of the military intervention in Rio de Janeiro was rendered invisible. This is connected to my third point - the focus on how her death affects the military intervention and not the genocide of Black people by police militias, the main subject of her activism. I will then problematise how her personal life was twisted, by firstly not disclosing her queerness and then by telling her life story with a sensationalist bent and depoliticising her cause. The final points are connected to the wider problem of fake news: some media vehicles interviewed a judge who was spreading fake news about Marielle without explicitly saying that the information was false, and the production of thousands of fake news items about Marielle.

Before the enormous public demonstrations and international coverage, Brazil's biggest news outlets were slow to understand the scale of the crime committed, perhaps because her death was not seen as 'newsworthy' as other topics, such as the Lava Jato operation or the diplomatic clash between Russia and the UK. Except for Rio de Janeiro's newspapers, it was only after the 15th of March (she was killed on the night of the 14th) that mainstream media such as Folha de S. Paulo gave the deserved attention to the case, with cover features, coverage of demonstrations and pressure for an investigation. Perhaps her death was not automatically perceived as "relevant" since she was not known in the media before she was killed. Her work had never been on mainstream media before and she only became a symbol when she passed away, yet another example of how important Black figures so often fail to receive the credit they deserve while alive.

Marielle's main focus was not considered newsworthy. She was not widely known by journalists, and therefore did not appear sufficiently important for news channels. She was also a daughter of Maré, born and raised in that comunidade. Such communities are mainly invisible to the media, except for celebrations of the "rare examples of victory" - people from the favelas doing the remarkable, such as winning international prizes or becoming very successful, which can be used as an example of 
meritocracy. Marielle was not in the spotlight before her death. But she was a member of the Rio city council, gaining the fifth-highest votes in the recent elections. Furthermore, she not only denounced police violence but also played a key role on a council committee overseeing the military intervention in Rio. In the days preceding her assassination, Franco publicly criticized violent actions committed by the military police operating in the Acari favela in Rio's north, including the murder of two young men. She was later shot four times in the head after leaving an event about Black women.

When Marielle's murder finally started to receive mainstream coverage, there was another problem: her criticism regarding Rio's military intervention was largely ignored or poorly mentioned in news pieces about her death, especially in coverage by Globo, the biggest media group in Brazil and very influential in Brazilian politics and public opinion. The military intervention, which is said to curb rising street crime and drug-related gang violence, was introduced on February 16th, after Michel Temer signed a decree placing the army in charge of Rio's security forces. This move has produced considerable controversy. Critics say it harkens back to Brazil's authoritarian past, echoes the increasing nostalgia for the military government on the far right, and ignores the failures and violence produced by the militarization of Rio's favelas ahead of the 2014 FIFA World Cup and 2016 Olympics. According to the daily Extra, homicides and carjacking actually increased during the first month of the military intervention. There were 6,731 violent deaths in Rio de Janeiro State in 2017, a 7.5 percent increase from the previous year. Only in January last year, 154 people were killed "in opposition to police intervention" and 6 police officers were killed.

Marielle was a vocal critic of the military intervention in Rio, saying that it threatened increase bloodshed without addressing the root causes of violence. In one of her last interviews, she said: "due to a recent period of decreased popularity of the illegitimate president Michel Temer and the press that favoured and enhanced what we understand as a feeling of insecurity in Rio especially during carnival, this process of federal intervention, which is called military intervention because it uses the armed forces, is legitimised. With an allusion of the pouring rain today, the city of Rio cries 
because of this intervention". ${ }^{3}$ But this criticism does not seem to interest Globo or even Folha de S. Paulo, who only mentioned this very briefly in a couple of pieces. Instead, the coverage was focused on the public outcry for her death and the future of the military intervention - if the army was in the streets for security reasons, how was it that a member of the city council was murdered in the heart of Rio? But then the exact opposite of her political message was strengthened: politicians including Michel Temer affirmed that this was proof that Rio is completely out of control and in need of more extreme security measures. Her assassination therefore 'proved' the relevance of the military intervention. Most reporters did not question such arguments, instead showing data that reinforced how violence had indeed increased in Rio in recent months. Then part of the press's rhetoric completely distorted Marielle's position, spreading the message "enough violence, we need peace" generalising peace, without disclosing which violence is being discussed. The violence against middle-class people who are robbed in privileged neighbourhoods in Rio? Police brutality in the favelas? Or the violence of Rio's militias, criminal organizations composed by police officers, security guards and politicians that sell protection, terrorize local communities, and extort local tradesmen? The most important TV news programme in Brazil, Jornal Nacional, even broadcasted a video about Marielle's cause made by activists, saying "this video is being shown to Brazil as a tribute and also an alert. Everything starts with respect. To life". Life, death, peace and violence were emptied of meaning in discourses that depoliticise the cause of Marielle's assassination. They appropriate political mobilisations, saying "Marielle presente", while emptying and alienating her cause. The coverage finishes as a big cry for help and the answer of politicians is clear: more military intervention, meaning more terror and repression of favelas, killing more of the same people (Black, young and poor).

\footnotetext{
3 Different experts have argued that the military intervention was a "populist" measure or a "electoral marketing" strategy to simulate that the government was doing something about the problem of public security when in fact the majority of the population did not believe that a military intervention could curb the rise of violence in Rio.
} 
And once again the genocide of Black people in Brazil is completely ignored. This was the main focus of Marielle's activism and the coverage of her death was the moment to discuss why she became a politician in the first place, which didn't happen. Instead, the focus was on her personality and life trajectory, repeating a neoliberal focus on the individual rather than the collective. Besides, her story can be suitably used by the white middle class to say that all Brazilians have the same opportunity in life. She completed the "hero's journey". Ironically, that is exactly why she was assassinated, for being a powerful and fearless Black woman who dared to denounce Brazilian state's necropolitics. Many men also did it, but a Black woman from the favela determined to fight for her community could not. It's not enough to be the successful Black woman in Brazil, where Black bodies are in the front line and will be executed first. Her execution, therefore, can be understood as part of the necropolitics she denounced - the destruction of human bodies and populations characterized as 'disposable' (Mbembe, 2003). Bodies that are not seen as 'profitable' by advanced capitalist logic are therefore not welcomed to work for the production of the market and are instead expelled from it and dumped in the informal and precarious market in the peripheral areas of the city. As a practice by the state, necropolitics dictates who is reducible to the 'unhuman', bodies without political status, who is "killable" and who is not—a series of extermination policies against the Black youth in the periphery of cities in Brazil and worldwide. Marielle can be seen as a "walking threat" to necropolitics: she not only survived it herself but was a symbol of resistance, a voice to her comunidade and unstoppable at her work in politics. In the eyes of those to whom she was a threat, she did not belong to the sphere of politics, she was a body outside the norms, which therefore had to be removed.

My next point is about queer invisibility. Anderson, the driver who was also shot dead in the same incident, was described in the media as "family man", a good husband that left wife and kids. Marielle also left a wife and a daughter. But a queer family is not considered 'family' in traditional parameters. In fact, her queerness was ignored in a huge piece aired on Jornal Nacional. Despite focusing on Marielle's personal story during six segments and several minutes, there was no mention of her queerness. Even when they translated a piece from The Guardian about Marielle, 
they erased the word gay in the title and translated 'Franco was a gay Black woman who defied the odds of Rio politics to win the fifth-highest vote count among council members when she was elected in 2016" to "Franco was a Black woman who defied the odds of Rio..." A couple of days later, however, with other outlets interviewing her widow, they changed the narrative and explored the drama involved in the loss of a partner, showing Monica (her partner) crying.

This leads to another important issue: sensationalism. Marielle's death was explored as an individual tragedy, not as a political assassination to silence Black communities who demand change. Her family and close friends appear crying in numerous closeup shots. The human tragedy, the loss of a loved one, the story of a remarkable woman that is portrayed as a character in a movie. Then meritocracy comes into play: she was born in the favela, she was pregnant at 19, she faced many difficult challenges but managed to go to higher education. With a master's degree in sociology and a place in parliament, she became a politician who defended the rights of her community. Look at her charisma, look at this beautiful smile! What an inspiration! Underlying this story there is a message of meritocracy, she exemplifies that with enough effort and dedication, others can choose education and success and not crime. Yes, she was a fantastic woman, but how did she 'make it'? Are we talking about the help she received from other activists and all that she had to go through? Furthermore, and most importantly, what made her pursue her political career? Are we talking about police abuse and inequality or are we just exploring an engrossing story for audience consumption? And after the sensationalism, the answer. During Globo's famous Sunday TV show Fantástico, there was a long and emotional story in which Marielle's charisma was again explored as well as the suffering of her loved ones. The next piece was about Michel Temer's renewed investment of hundreds of millions into the military intervention in Rio. Case settled.

This sensationalism is compounded by the undue attention given by the media to a judge quoted saying that Marielle was involved with criminals. The majority of readers pay attention only to the title of a story without reading it through. This is important when a handful of newspapers published the judge's opinion, with titles varying between "Marielle was engaged with Comando Vermelho" (a famous 
criminal group) and "Marielle was engaged with criminals and is an ordinary corpse". Combined with a judge's authority, the headlines offer a condemning view of Marielle; however, the judge was reproducing a message she had received on WhatsApp without checking the facts. The title should be "Judge reproduces fake news about a non-existent connection between Marielle and criminal groups". This was later questioned and the judge retracted her statement, without apology. However, the damage was done and there was no way to remove the narrative from the public domain.

These problems went far beyond traditional media coverage, however, not only threatening traditional journalism, but society as a whole: the unbelievable production and spread of fake news about Marielle. Many far-right YouTube channels spread fake news with the intent to destroy her image. The Free Brazil Movement, a neoliberal youth group who had an important role in the impeachment of Dilma Rousseff that put Michel Temer in power, engaged in enormous efforts to link Marielle to organized crime, trying to link the murderers to drug dealers or militias. This idea reinforced ignorant and distressingly common discourse that 'Marielle was killed by those who she defended, criminals'. While we still have no concrete information about who is truly behind the crime, many followers of the page will believe that narrative. In a few days, there were 15 thousand denouncements of slander, defamation and false accusation registered against Marielle. After this, many media vehicles published stories refuting such fake news. It is interesting to note here that mainstream media put itself in the crossfire of fake news sources while propagating news of dubious origin such as the declaration of the judge mentioned earlier.

In this article, I have pointed out how Marielle was inscribed in a continuum of subjugation of life to the power of death. I have also highlighted how her struggle and her death have been appropriated and depoliticised by the media. To conclude, I would like to highlight the connection between the 'cleansing' of Franco's life and necropolitics, not in the sense of the execution itself but the necropower that subjects populations to conditions of life. In its own way, different media outlets have constructed notions of how Marielle should have lived and how she should have died. 
And the fading of her radicalness in mainstream media accounts is analogous to the their take on her struggles: the military intervention and the genocide of Black people. While the cleansing of her radical politics can be attributed to the condition of the media and journalism in cultures where neoliberal logics are internalised as necessary and neutral rather than ideological, the picture of Marielle described by the media radically clashes with what Marielle truly stood for. It is another example of how mainstream media internalises neoliberal logics hostile to politics.

\section{References}

Mbembe, Achille. 2003. Necropolitics. Public Culture 15(1):11-40. Patterson, Orlando 